\title{
Corporate Culture Differences between Taiwan and Vietnam
}

\author{
Massoud Moslehpour ${ }^{1}$, Van Kien Pham ${ }^{2}$, İsmail Bilgiçli ${ }^{3} \&$ Huynh Van Nguyen ${ }^{4}$ \\ ${ }^{1}$ College of Management, Asia University, Taiwan \\ ${ }^{2}$ Banking University Ho Chi Minh City, Vietnam \\ ${ }^{3}$ Sakarya University Karasu MYO, Turkey \\ ${ }^{4}$ Chang Gung University, Taiwan \\ Correspondence: Massoud Moslehpour, College of of Management, Asia University, 500, Lioufeng Rd., Wufeng, \\ Taichung 41354, Taiwan. Tel: 886-2332-3456 Ext. 1962.
}

Received: February 3, 2016

doi:10.5430/jms.v7n1p81
Accepted: February 10, 2016

Online Published: February 15, 2016

URL: http://dx.doi.org/10.5430/jms.v7n1p81

\begin{abstract}
The purpose of this study is to investigate and compare corporate culture differences between Taiwan and Vietnam. The concept of corporate culture is adopted from Trompenaars and Turner's four types of corporate culture. Trompenaars and Turner (2012) categorized corporate culture into four main types: the Family, the Eiffel Tower, the Guided Missile and the Incubator. The ANOVA approach is employed to describe and analyze the collected data. A total of 477 employees from public and private corporate sectors in Taiwan and Vietnam participated in this study. Out of 477 respondents 246 are Taiwanese and 231 are Vietnamese. The competing value framework (CVF) (Cameron \& Quinn, 2006) is the main reference for developing the questionnaire. The results of the study show that there are significant differences in corporate cultures between Taiwan and Vietnam on three out of four aspects of corporate culture introduced in this study.
\end{abstract}

Keywords: corporate culture, family, the Eiffel Tower, the guided missile, the incubator

\section{Introduction}

In 21st century, the world has become a global village and businesses have also become global. Just recently, Volkswagen chief executive, Matthias Mueller, called upon the car maker's executives to help change the corporate culture (Varnholt, 2015). Organizations are venturing beyond national boundaries in the pursuit of business opportunities. Global leaders must learn the customs, courtesies, and business protocols of their counterparts from other countries. They also need to understand the national character, management philosophies, and mindsets of the people (Harris, Moran, \& Moran, 2004). For employees, multinational corporations require employees to adapt to different cultures, customs, social practices, values, economic, political systems and management approaches. As a result, they can work with other employees from differing backgrounds. Therefore, a need for understanding one's own national culture as well as corporate culture as well as others' is of great importance in this borderless world.

Nowadays, more and more Taiwanese companies open subsidiaries or joint venture with other countries to open a new company. Among Asian countries, Taiwanese investors are eyeing Vietnam as an attractive destination. Taiwanese companies pledged a total investment capital of around US\$23.3 billion in Vietnam from 1988 to September 2011, making Taiwan Vietnam's second largest foreign investor. Each Taiwan-invested project is capitalized at over US\$10 million (Thu, 2011). On the other hand, there are over 85,650 Vietnamese guest workers who are working in Taiwan. Taiwanese companies bring their corporate culture to Vietnam and Vietnamese workers come to Taiwan with their own national culture (Thu, 2011). Therefore, understanding the impact of national culture on corporate culture and identifying the cultural differences between Vietnam and Taiwan are both necessary in the trading process between the two countries in order to achieve best results and avoid some misunderstandings.

Therefore, this study attempts to contribute to the corporate culture literature through a cross cultural comparative study with the links between them and specific between two countries of origin: Taiwan and Vietnam. Corporate culture is described by Trompenaars' four types of corporate culture. Although there were many studies related to corporate culture before but it seemed to be separately conduct. For example, just for Taiwanese's corporate culture itself and the study related to the both countries are limited. This study will be conducted in both countries and make 
a comparison about the corporate culture. This study would be beneficial to Taiwanese investors who want to do business with Vietnamese and Vietnamese labors who want to work in Taiwan.

\subsection{Objective of the Study}

Culture only exists by comparison - one society is compared to other societies. An understanding of cultural differences helps people to adjust their communication style and behavior appropriately in any business practices. This study's objectives is to examine the complex relationship regarding to corporate culture with the purpose of determining if there are any significant differences between Taiwan and Vietnam in term of corporate culture.

\subsection{What Is Culture?}

Culture is a complex concept with a variety of definitions which range from general to specific areas of interest. In general, culture is a distinct human means of adapting to circumstances and transmitting the coping skill and knowledge to subsequent generations. "Culture gives people a sense of who they are, how they should behave, what they should be doing" (Harris et al., 2004, p.4). In specific field, as two anthropologists Kroeber and Kluckhohn (1952) cite, there were over 160 different definitions of culture. Their definition on culture consists of patterns, explicit and implicit, of and for behavior acquired and transmitted by symbols, constituting the distinctive achievements of human groups, including their embodiments in artifacts. The essential core of culture consists of traditional ideas and especially their attached values. Culture systems may be considered as products of action, and on the other as conditioning elements of further action. Patterns in culture can be transmitted by symbols and Damen (1987) mentioned that culture is a learned and shared human pattern or model for living; a day to day living patterns. These patterns and models pervade all aspects of human social interaction. "Culture is the primary adaptive mechanism of mankind" (Damen, 1987). As defined by Schein (2004), culture is like an iceberg with three layers but just a small percentage of visible features can be seen above the surface of water. Below the surface are the espoused values of the culture and the deepest are the basic underlying assumptions. Hofstede (2010) in turn sees culture as the collective programming of the mind which distinguishes the members of one category of people from another. On the other hand, Trompenaars \& Turner (2012) defines culture in a practical and friendly approach "Culture is the way in which a group of people solves problems and reconciles dilemmas". Whatever the definitions of culture are the hands-on or philosophical perspectives, culture is indeed a guideline for everyday life, communication and work.

\subsection{Types of Corporate Culture}

Maybe the most popular definition of corporate culture is the way we do things around here (Deal \& Kennedy, 1999). This definition suggests that changing a corporate culture is simply changing the way things are done such as: 1) flattening the organization structure, 2) introducing a new reward system, 3) drafting a "code of conduct", 4) specifying acceptable and unacceptable behaviors, and 5) communication in for of language ability. Gregg (2015) maintains that in today's modern workplace principles of equal opportunity and diversity leave little room for the authoritarian image of the corporate culture. Sun (2008) pointed out that corporate culture is a system of shared values and beliefs that interact with a company's people, organization structures, and control systems to produce behavioral norms.

Generally speaking, corporate culture has been defined as stable attitudes, beliefs and values held in common by organizational members, shared normative beliefs and behavioral expectations. Culture provides better ways of thinking, feeling and reacting that could help managers to make decision and arrange activities of organization. A number of corporate culture typologies have been developed to distinguish among different corporate cultures. Maher (2000) distinguishes between two dimensions of corporate culture and emphasize the need to find a balance between the competing values of each dimension: control versus flexibility and internal focus versus external focus. This model leads to four types of corporate culture: the hierarchy culture; the market culture, the clan culture and the adhocracy culture. Huang, Li, Meschke and Guthrie (2015) concluded that corporate culture influences firm performance. Organizational culture is not just a set of rules that we can announce in some bulletin board and expect employees to follow. Even if you hire the best combination of employees, it is just not going to happen that way. Corporate culture has to be designed with the right tools, from the processes to the incentives that lead to good organizational behaviors and great outcomes.

Based on dimensions of national culture, Hofstede (2010) also set up types of corporate cultures derived from his two national dimensions: uncertainty and power distance. There are four types: the pyramid, the machine, the family and the village market. This study adopted Trompenaars' organizational culture typology. The four categories in this study were originally introduced by Charles Handy (1993). Later, Trompenaars \& Turner (2012) classified corporate culture into four main types: the Family, the Eiffel Tower, the Guided Missile and the Incubator. These four types 
are based on two value dimensions: equality versus hierarchy and orientation to the person versus orientation to the task. This study employs Trompenaar \& Turner (2012) definition and categorization of corporate culture. The characteristics of Trompenaars' dimensions of corporate culture are shown in Figure 1.

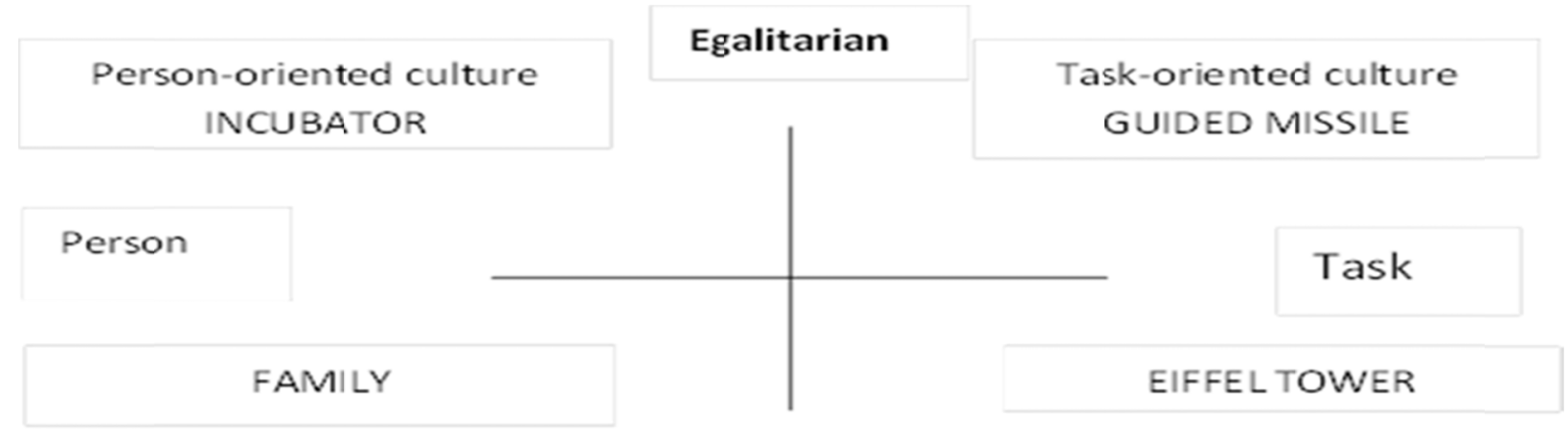

Hierarchical

Figure 1. The Trompenaars corporate culture model

\subsubsection{The Family Culture (FAM)}

This culture is characterized by strong emphasis on the hierarchy and orientation toward the person. This kind of corporate culture has a sense of the "father" as owners or managers who have experiences and authority exceeding of his children as employees. This type of culture can be found in actual family companies and in companies that originate from family enterprises, but publicly owned companies may have a family atmosphere as well. The family corporate culture tends to be high context which focuses on collectivism, preferring group harmony and consensus to individual achievement. And people in these cultures are less governed by reason than by intuition or feelings. Because it is close face-to-face relationships (Trompenaars \& Turner, 2012), relationships seem to be diffuse. Working and living are tied together, management board concern about employees' life, housing and wages, and etc. Therefore, in this culture, "who" is doing something is more important than "what" is being done. Work satisfaction is based on loyalty and the accumulation of power and status over time.

\subsubsection{The Eiffel Tower Culture (EIF)}

Trompenaars and Turner (2012) have chosen the Eiffel Tower in Paris to symbolize this culture type "because it is steep, symmetrical, narrow at the top and broad at the base, stable, rigid and robust". It's characteristic to some degree assemble that of the work hierarchy in role orientated corporate. And more importantly, its structure, too, is more important than its function (Trompenaars \& Turner, 2012). Everyone has a precise job description no matter what kinds of jobs and what your role is. Bosses have the authority to order employees to work according to their clear instructions. Bosses just have power in working place. Behind the office, everyone is the same, separating clearly between life and work. This culture is stable, predictable, safe and reliable. Work satisfaction is based on building competence in a well-defined area (Trompenaars, 2000; Bakka et al., 2001).

\subsubsection{The Guided Missile Culture (GUI)}

This culture is characterized by a strong emphasis on equality and an orientation toward the task. People in this culture tend to work as teams or project groups to complete the tasks with motto "getting things done". The activities in this culture are involved in extensive research and development activities. They are constantly subject to change and have to create temporary task teams to meet their future needs. Information and expertise are the skills that are of value here. The culture is represented best by a net or lattice work. Guided missile cultures are egalitarian because people are evaluated on what they can contribute to the team and on their performance, and not on any status which is ascribed to them based on other criteria. Work satisfaction is based on the reward attached to the completed task (Trompenaars, 2000).

\subsubsection{The Incubator Culture (IN)}

This culture includes both person-oriented and egalitarian. The purposes are free individuals from performing routine tasks in order to enable more creative activities and shrink minimize time spent on self-maintenance. The incubator 
culture is egalitarian because anyone, regardless of their status may have ideas which are totally able to become winning ideas. It is person- oriented cultures because creativity, passion and improvisation skills of each individual are highly appreciated and applied to pragmatic situations. Work satisfaction is based on continuous learning, passion for the work itself, and celebrating new discoveries. The above discussion is summarized in Table 1.

Table1. Characteristics of the four corporate cultures

\begin{tabular}{|c|c|c|c|c|}
\hline $\begin{array}{l}\text { Corporate } \\
\text { Culture }\end{array}$ & $\begin{array}{l}\text { Family } \\
\text { (FAM) }\end{array}$ & $\begin{array}{l}\text { Eiffel Tower } \\
\text { (EIF) }\end{array}$ & $\begin{array}{c}\text { Guided missile } \\
\text { (GUI) }\end{array}$ & $\begin{array}{c}\text { Incubator } \\
\text { (IN) }\end{array}$ \\
\hline $\begin{array}{l}\text { Relationship } \\
\text { between } \\
\text { employees }\end{array}$ & $\begin{array}{l}\text { Diffuse relationships } \\
\text { to organic whole to } \\
\text { which one is bonded }\end{array}$ & $\begin{array}{c}\text { Specific role in } \\
\text { mechanical system } \\
\text { of required } \\
\text { interactions }\end{array}$ & $\begin{array}{l}\text { Specific tasks in } \\
\text { cybernetic system } \\
\text { targeted upon } \\
\text { shared objectives }\end{array}$ & $\begin{array}{c}\text { Diffuse, spontaneous } \\
\text { relationships growing } \\
\text { out of shared creative } \\
\text { process }\end{array}$ \\
\hline $\begin{array}{l}\text { Attitude to } \\
\text { authority }\end{array}$ & $\begin{array}{l}\text { Status is ascribed to } \\
\text { parent figures who are } \\
\text { close and powerful }\end{array}$ & $\begin{array}{c}\text { Status is ascribed } \\
\text { to superior roles } \\
\text { who are distant yet } \\
\text { powerful }\end{array}$ & $\begin{array}{l}\text { Status is achieved } \\
\text { by project group } \\
\text { members who } \\
\text { contribute to } \\
\text { targeted goal }\end{array}$ & $\begin{array}{l}\text { Status is achieved by } \\
\text { individuals } \\
\text { exemplifying } \\
\text { creativity and growth }\end{array}$ \\
\hline $\begin{array}{l}\text { Ways of } \\
\text { thinking } \\
\text { and } \\
\text { learning }\end{array}$ & $\begin{array}{l}\text { Intuitive and holistic, } \\
\text { lateral and error } \\
\text { correcting }\end{array}$ & $\begin{array}{l}\text { Logical, analytical, } \\
\text { vertical and } \\
\text { rationally efficient }\end{array}$ & $\begin{array}{l}\text { Problem centered, } \\
\text { professional, } \\
\text { practical and } \\
\text { cross-disciplinary }\end{array}$ & $\begin{array}{l}\text { Process oriented, } \\
\text { creative ad hoc, } \\
\text { inspirational }\end{array}$ \\
\hline $\begin{array}{l}\text { Attitudes to } \\
\text { people }\end{array}$ & Family members & Human resources & $\begin{array}{l}\text { Specialists and } \\
\text { experts }\end{array}$ & Co-creators \\
\hline $\begin{array}{l}\text { Ways of } \\
\text { changing }\end{array}$ & $\begin{array}{c}\text { "Father" changes } \\
\text { course }\end{array}$ & $\begin{array}{c}\text { Change rules and } \\
\text { procedures }\end{array}$ & $\begin{array}{c}\text { Shift aim as target } \\
\text { moves }\end{array}$ & Improvise and attune \\
\hline $\begin{array}{c}\text { Ways of } \\
\text { motivating } \\
\text { and } \\
\text { rewarding }\end{array}$ & $\begin{array}{l}\text { Intrinsic satisfaction in } \\
\text { being loved and } \\
\text { respected. } \\
\text { Management by } \\
\text { subjective }\end{array}$ & $\begin{array}{l}\text { Promotion to } \\
\text { greater position, } \\
\text { larger role. } \\
\text { Management by } \\
\text { job description }\end{array}$ & $\begin{array}{l}\text { Pay or credit for } \\
\text { performance and } \\
\text { problems solved. } \\
\text { Management by } \\
\text { objectives }\end{array}$ & $\begin{array}{l}\text { Participating in the } \\
\text { process of creating } \\
\text { new realities. } \\
\text { Management by } \\
\text { enthusiasm }\end{array}$ \\
\hline $\begin{array}{l}\text { Criticism } \\
\text { and conflict } \\
\text { resolution }\end{array}$ & $\begin{array}{l}\text { Turn other cheek, save } \\
\text { others' faces, do not } \\
\text { lose power game }\end{array}$ & $\begin{array}{c}\text { Criticism is } \\
\text { accusation of } \\
\text { irrationality unless } \\
\text { there are } \\
\text { procedures to } \\
\text { arbitrate conflicts }\end{array}$ & $\begin{array}{l}\text { Constructive } \\
\text { task-related only, } \\
\text { then admit error } \\
\text { and correct fast }\end{array}$ & $\begin{array}{l}\text { Must improve } \\
\text { creative idea not } \\
\text { negate it }\end{array}$ \\
\hline
\end{tabular}

Source: (Trompenaars \& Turner, 2012)

\section{Methodology}

\subsection{Research Hypotheses and Model}

The research hypotheses are constructed based on the research objectives and the extensive review of literature. A total of five main hypotheses are presented below and also in Figure 2. 
H1: There is significant difference between Taiwan and Vietnam Family culture (FAM) aspect of corporate culture.

H2: There is significant difference between Taiwan and Vietnam Eiffel Tower culture (EIF) aspect of corporate culture.

H3: There is significant difference between Taiwan and Vietnam Guided Missile culture (GUI) aspect of corporate culture.

H4: There is significant difference between Taiwan and Vietnam Incubator culture (IN) aspect of corporate culture.

H5: There is significant difference between Taiwan and Vietnam corporate culture.

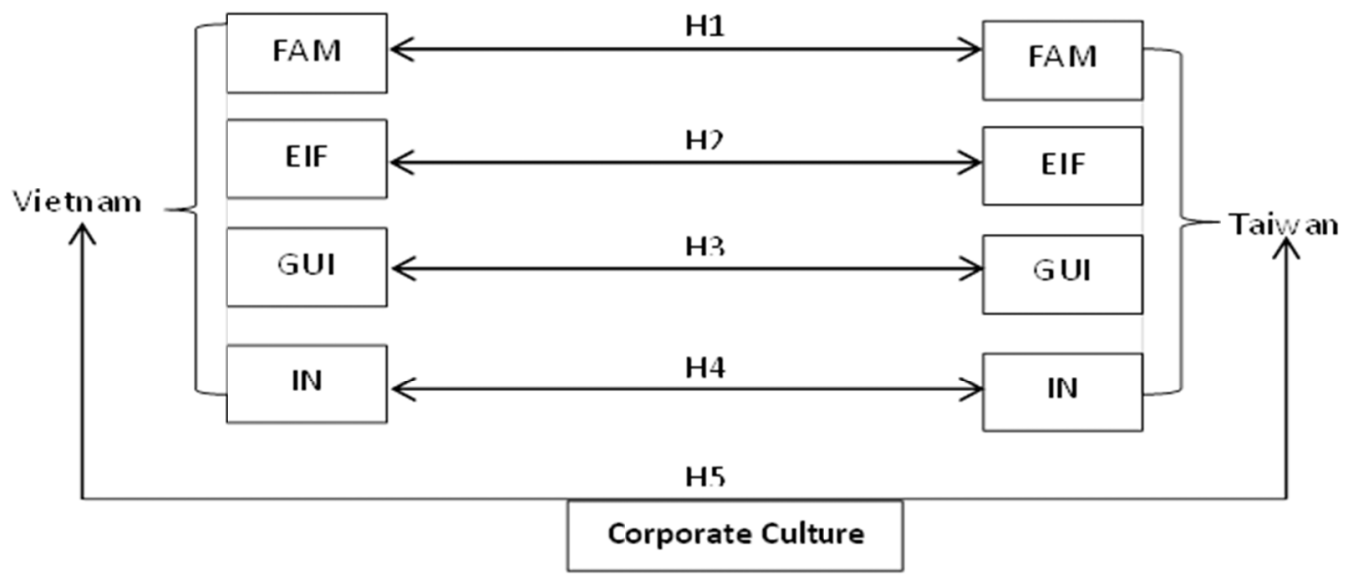

Figure 2. Research model

\section{Results}

\subsection{Sample Characteristics}

A total of 600 questionnaires were distributed for this research with 300 for Taiwan and 300 for Vietnam. Eventually, a total of 246 and 231 questionnaires returned from Taiwanese and Vietnamese participants, respectively. The gender distribution for the sample is 96 male for Taiwanese respondents and 78 for Vietnamese respondents. On the other hand, we have 150 Taiwanese female and 153 Vietnamese female. The dominant gender in both countries is female. Regarding education, the majority of the sampled population held undergraduate degree in Taiwan (70.7\%). However, in Vietnam, participants with graduate degree have a larger percentage (55.8\%). The demographic information is summarized in Table 2 .

Table 2. Sample characteristics

\begin{tabular}{|c|c|c|c|c|c|c|}
\hline Country & & sory & Percent & & Category & Percent \\
\hline \multirow{4}{*}{ Taiwan } & \multirow{4}{*}{ Gender } & & & \multirow{4}{*}{ Education } & High school student & $14.2 \%$ \\
\hline & & Male & $39 \%$ & & Undergraduate student & $70.7 \%$ \\
\hline & & Female & $61 \%$ & & Graduated student & $12.2 \%$ \\
\hline & & & & & Postgraduate & $2.8 \%$ \\
\hline \multirow{4}{*}{ Vietnam } & \multirow{4}{*}{ Gender } & & & \multirow{4}{*}{ Education } & High school student & $3.5 \%$ \\
\hline & & Male & $33.8 \%$ & & Undergraduate student & $32 \%$ \\
\hline & & Female & $66.2 \%$ & & Graduated student & $55.8 \%$ \\
\hline & & & & & Postgraduate & $8.7 \%$ \\
\hline
\end{tabular}




\subsection{Validity and Reliability Test}

As discussed early, corporate culture includes Family Culture (FAM), Eiffel Tower Culture (EIF), Guided Missile Culture (GUI) and Incubator Culture (IN). In order to test the data's validity, this study applies the principal components method using Varimax rotation dividing the questions into four factors with eigenvalue greater than 1.0. Bartlett's test of sphericity and Kaiser-Meyer-Olkin (KMO) measure of sampling adequacy were used to test the appropriateness of factor analysis. The result for all the correlations of factor analysis shows that the value of Kaiser-Meyer-Olkin (KMO) is acceptable (0.787). Four questions (Q28, Q34, Q35 and Q42) due to low factor loading were deleted. In addition, the statistical test for the Bartlett test of sphericity was significant with $p=0.000$. That confirms factor analysis is appropriate. The attributes of each factor and their respective loadings are presented in Table 3.

Factors are also examined for their reliability through the Cranach's alpha approach. The result of reliability analysis is also showed in Table 3. As a result, all factors are acceptable because a measure scale is said to be reliable when the coefficient alpha or Cronbach's alpha is greater than 0.6. The cumulative extracted value by the four factors is also acceptable (63.913\%).

Table 3. Expletory factor analysis and reliability results

\begin{tabular}{|c|c|c|c|c|c|}
\hline Variables & Item & Factor loading & $\begin{array}{c}\text { Cronbach's } \\
\text { Alpha }(\alpha)\end{array}$ & $\begin{array}{l}\text { Mean } \\
\text { Taiwan }\end{array}$ & $\begin{array}{c}\text { Mean } \\
\text { Vietnam }\end{array}$ \\
\hline & Q27 & .709 & & & \\
\hline FAM & Q29 & .656 & .617 & 3.60 & 3.73 \\
\hline & Q30 & .793 & & & \\
\hline EIF & Q36 & .714 & & & \\
\hline EIr & Q37 & .805 & .762 & 3.13 & 3.18 \\
\hline & Q38 & .603 & & & \\
\hline GUU & Q31 & .860 & 666 & 340 & 310 \\
\hline ( & Q32 & .801 & .000 & 0.40 & 5.10 \\
\hline & Q33 & .710 & & & \\
\hline IN & Q39 & .836 & & & \\
\hline IIN & Q40 & .851 & .746 & 4.11 & 4.01 \\
\hline & Q41 & .704 & & & \\
\hline Validity (KMO) & \multicolumn{5}{|c|}{.787} \\
\hline Reliability $(\alpha)$ & \multicolumn{5}{|c|}{.784} \\
\hline P-Value & \multicolumn{5}{|c|}{$.000<0.5$} \\
\hline Cumulative \% & \multicolumn{5}{|c|}{$63.913>50 \%$} \\
\hline
\end{tabular}

\subsection{Hypotheses Testing}

Since the data proven to show good validity and reliability, next we look to answer the research questions. ANOVA is applied to check this relationship (Malhotra, 2010). The study uses a total of five major hypotheses to compare the differences between Vietnam and Taiwan in terms of corporate culture. The findings of mean comparison are summarized in Table 4. Table 4 summarizes the between group effects (effects due to the experiment) and within group effects (this is the unsystematic variation in the data). The between group effect is the overall experimental effect (cultural differences between two countries). In this row we are told the sums of squares for the model (SSM=2.002 for FAM, 0.336 for EIF, 10.773 for GUI, and 4.345 for IN).

The sum of squares for the model represents the total experimental effect whereas the mean squares for the model represent the average experimental effect. The row labeled within group gives details of the unsystematic variation within the data (the variation due to different culture in each country). In addition, Table 4 tells us how much unsystematic variation exists (the residual sum of squares, SSR). It then gives the average amount of unsystematic variation, the residual mean squares (MSR). The test of whether the group means are the same is represented by the F 
ratio for the combined between group effect. The value of this ratio is $5.359,0.555,22.830,10.170$, and 15.523, respectively. The final column labeled sig. indicates how likely it is that an $\mathrm{F}$ ratio of at least that size would have occurred if there were no differences between means. In this case, there is a probability of .000 (that's less than a .1\% chance). In more detail, the mean difference between Vietnam and Taiwan are significant at the 0.05 level for Family Culture (0.021) and Incubator (0.002) and at the 0.001 level for Guided Missile $(0.000)$ and Corporate Culture $(0.000)$. Eiffel Tower (0.457), however, does not show any significant differences between two countries.

Table 4. Mean comparison - ANOVA

\begin{tabular}{|c|c|c|c|c|c|c|}
\hline \multicolumn{2}{|c|}{ FACTOR } & \multirow{2}{*}{$\begin{array}{c}\begin{array}{c}\text { Sum of } \\
\text { Squares }\end{array} \\
2.002\end{array}$} & \multirow{2}{*}{$\begin{array}{l}\mathrm{df} \\
1\end{array}$} & \multirow{2}{*}{$\begin{array}{c}\text { Mean Square } \\
2.002\end{array}$} & \multirow{2}{*}{$\begin{array}{c}\mathrm{F} \\
5.359\end{array}$} & \multirow{2}{*}{$\begin{array}{l}\text { Sig. } \\
\mathbf{. 0 2 1 *}\end{array}$} \\
\hline \multirow{3}{*}{ FAMILY } & Between Groups & & & & & \\
\hline & Within Groups & 177.415 & 475 & .374 & & \\
\hline & Total & 179.416 & 476 & & & \\
\hline \multirow{3}{*}{ EIFEL TOWER } & Between Groups & .336 & 1 & .336 & .555 & .457 \\
\hline & Within Groups & 287.510 & 475 & .605 & & \\
\hline & Total & 287.845 & 476 & & & \\
\hline \multirow{3}{*}{$\begin{array}{l}\text { GUIDED } \\
\text { MISSILE }\end{array}$} & Between Groups & 10.773 & 1 & 10.773 & 22.830 & $.000 * * *$ \\
\hline & Within Groups & 224.129 & 475 & .472 & & \\
\hline & Total & 234.901 & 476 & & & \\
\hline \multirow{3}{*}{ INCUBAT } & Between Groups & 4.345 & 1 & 4.345 & 10.170 & $.002 * *$ \\
\hline & Within Groups & 202.929 & 475 & .427 & & \\
\hline & Total & 207.274 & 476 & & & \\
\hline \multirow{3}{*}{$\begin{array}{l}\text { CORPORATE } \\
\text { CULTURE }\end{array}$} & Between Groups & 3.386 & 1 & 3.386 & 15.523 & $.000 * * *$ \\
\hline & Within Groups & 103.622 & 475 & .218 & & \\
\hline & Total & 107.009 & 476 & & & \\
\hline
\end{tabular}

The mean comparison shows that there are significant differences between Taiwan and Vietnam in term of Family Culture, Guided Missile Culture, Incubator culture, and Corporate Culture in general. Therefore, H1, H3, H4 and H5 are accepted, while $\mathrm{H} 2$ is rejected. These findings are indicated in Table 5.

Table 5. Conclusion on the research hypotheses

\begin{tabular}{ll}
\hline \multicolumn{1}{c}{ Hypothesis } & result \\
\hline H1: There is significant difference between Taiwan and Vietnam Family culture (FAM) & Accepted \\
aspect of corporate culture. & \\
H2: There is significant difference between Taiwan and Vietnam Eiffel Tower culture & rejected \\
(EIF) aspect of corporate culture. & \\
H3: There is significant difference between Taiwan and Vietnam Guided Missile culture & Accepted \\
(GUI) aspect of corporate culture. & Accepted \\
H4: There is significant difference between Taiwan and Vietnam Incubator culture (IN) & aspect of corporate culture. \\
H5: There is significant difference between Taiwan and Vietnam corporate culture. & Accepted \\
\hline
\end{tabular}

\section{Discussion}

This study is conducted to determine if there are any differences between Taiwan and Vietnam in terms of corporate 
culture. In so doing, Trompenaars and Turner's concept of corporate culture is adopted. The four categories of corporate culture as classified by Trompenaars and Turner includes: 1) Family culture, 2) Eiffel Tower culture, 3) Guided Missile culture and 4) Incubator culture. Based on that, a total of five major hypotheses were tested to answer the research questions. The overall result of this study concludes that there are significant differences between Vietnam and Taiwan in terms of corporate culture.

This means that a set of shared philosophies, ideologies, values, norms and attitudes within Taiwanese and Vietnamese organization is different. Particularly, with regard to Family culture, the findings indicate that there exists a significant difference between the two countries. This type of culture can be found in actual family companies and in companies that originate from family enterprises. In Vietnam family relationships among employees and members of the company are stronger than Taiwan. Table 3 indicates the mean value for Vietnam higher than Taiwan. In Vietnam, compared to Taiwan, working and living are more tied together. In Vietnamese corporate culture one can expect more intuition and less reason when it comes to the comparison between Taiwan and Vietnam. This diffused family corporate culture is also influenced by China as Vietnam used to be a Chinese colony. It is different from Taiwan because there have many changes in Taiwanese companies recently. As a new industrial country, the relationship between members in Taiwanese organization is more exposed than Vietnam.

In relation to the Eiffel tower, there are no differences between Vietnam and Taiwan since companies in both countries tend to have centralized power distribution. In both countries the work hierarchy is the dominant characteristic. Everyone has a precise job description no matter what kinds of jobs and what your role is. Bosses have the authority to order employees to work. In both countries everyone has a precise job description regardless of type of job and the role of the employee.

Regarding the guided missile, Vietnam and Taiwan are different. This culture is characterized by a strong emphasis on equality and an orientation toward the task. Taiwanese companies often complete tasks by teams and project groups focusing on the flexibility, while Vietnamese companies prefer to have an Eiffel tower approach.

The Incubator culture in Vietnam is also different from Taiwan. This type of corporate culture is based on freeing individuals from performing routine tasks in order to enable more creative activities and minimize the time spent on self-maintenance. Employees in Taiwan are free from routines to contribute more effort into creative activities because many Taiwanese companies focus on hi-tech business, while staffs in Vietnam have a fewer chance to devote their efforts. Companies in Taiwan are more focused in design and innovation; however Vietnamese factories are more about efficient production.

Finally, when looking at the differences in corporate culture in general between Taiwan and Vietnam, the results indicate that there are significant differences between the corporate cultures of the two countries.

\section{Conclusion}

The results of this study confirm that there are significant differences between Taiwan and Vietnam in terms of corporate culture. Therefore, practitioners and managers should pay attention to the characteristics of this dimension to determine which type of corporate culture is effective in various cultures and how to achieve desired outcome in contexts. There is a famous saying: "When in Rome, do as the Romans do" certainly applies to cross cultural communication and globalization of businesses worldwide. The results of this study reiterate that Taiwanese organization should be more aware of the employees feeling of freedom, happiness, confusion, stress or other cultural aspects. Employees' well-being will link to the organization's performance and effectiveness. Furthermore, when foreign countries want to invest in Taiwan or Vietnam, whatever their type of organization might be, they should take into account the significant influence of corporate culture on productivity and profitability. In Asia, the tendency of restraint is usually strong. Therefore, employees usually feel unhappy or have the sense of helplessness. So, managers should pay more attention to this in order to avoid misunderstandings.

In Vietnam, employees have a sense of stability. If they feel the job is stable and they can earn enough for their life, they just want to do the same job as long as possible. Therefore, when foreign investor wants to invest to Vietnam, they should show a long term planning. Also in staffing, the labor contract should be considered for long term. Taiwanese employees tend to avoid the ambiguous or unknown situations. An emotional need for rules is busy and working hard as well as having the balance between work and personal life. In planning, there is a need for more detail and short term feedback. For human resources, there is a need to pay attention to the process of staffing and appraisal that must base on skills, abilities, evaluation on what you achieve and what you know (Schneider, 1988). Furthermore, in Vietnam, employees tend to accept the unequal status and power, a strong propensity to save and invest, thriftiness, perseverance in achieving results. Human resources in the process of staffing and compensation 
should be aware of the acceptance of a wide salary range and incentives granted on group basis.

\section{References}

Bakka, J. F., Fivelsdal, E., \& Lindkvist, L. (1999). Organisationsteori-struktur, kultur,processer. Malmo: Liber Ekonomi.

Cameron, K. S., \& Quinn, R. E. (2006). Diagnosing and Changing organizational culture: Based on the Competing Values Framework. USA: Jossey - Bass.

Damen, L. (1987). Culture Learning: The Fifth Dimension in the Language Classroom. Addison-Wesley Pub.

Deal, T. E., \& Kennedy, A. A. (1999). The New Corporate Cultures. Cambridge, MA: Perseus.

Gregg, M. (2015, September 25). How Sexism Shaped Corporate Culture. The Atlantic. Retrieved from http://www.theatlantic.com

Handy, C. (1993). Understanding organizations ( $4^{\text {th }}$ ed.). USA: Oxford University Press.

Harris, P. R., Moran, R. T., \& Moran, S. V. (2004). Managing cultural differences $\left(6^{\text {th }}\right.$ ed.). U.S.A: Elsevier Butterworth - Heinemann.

Hofstede, G. (1980). Culture consequences: International differences in work-related values. U.S.A: Sage.

Hofstede, G. (2011). Dimensionalizing cultures: The Hofstede Model in Context. Online reading in psychology and culture, Unit, 2(1). http://dx.doi.org/10.9707/2307-0919.1014

Hofstede, G. (2012). Cultural dimensions. Retrieved from http://geerthofstede.com/dimensions.html

Hofstede, G., \& Bond, M. (1988). The confucious connection: From cultural roots to economic growth. Organizational Dynamics, 16, 5-21.

Hofstede, G., \& Hofstede, G. J. (2010). Cultures and Organizations: Software of the mind (2nd ed.). Mc Graw Hill.

Hofstede, G., \& Minkov, M. (2010). Long- versus short-term orientation: new perspectives. Asia Pacific Business Review, 16(4), 493-504. http://dx.doi.org/10.1080/13602381003637609

Hofstede, G., Hofstede, G. J., Minkov, M., \& Vinken, H. (2008). The value survey module. Retrieved from $\mathrm{http}: / /$ www.geerthofstede.nl/vsm-08

Huang, M., Li P., Meschke, F., Guthrie, J. P. (2015). Family Firms, Employee Satisfaction, and Corporate Performance. Journal of Corporate Finance, 34, 108-127. http://dx.doi.org/10.1016/j.jcorpfin.2015.08.002

Kroeber, A. L., \& Kluckhohn, C. (1952). Culture: A critical review of concepts and definitions. Peabody Museum of American Archeology and Ethnology, XLVII-ND, 1(1952), 47.

Maher, M. A. (2000). Diagnosing and changing organizational culture: Based on the competing value framework. Journal of Organizational Change Management, 13(3), 300-303.

Malhotra, N. K. (2010). Marketing Research: An applied Orientation (6 ${ }^{\text {th }}$ ed.). United States of America: Pearson Education.

Schein, E. H. (2004). Organizational Culture and Leadership ( $3^{\text {rd }}$ ed.). United States of America: Jossey-Bass.

Schneider, S. C. (1988). National vs. Corporate Culture: Implications for Human Resource Management. Human resource management, 27(2), 231-246. http://dx.doi.org/10.1002/hrm.3930270207

Sun, S. (2008). Organizational culture and its themes. International Journal of Business and Management, 3(12), 137-141.

Thu, T. (2011). Taiwan investors plan to move to Vietnam, The Saigon Times Daily. Retrieved from http://english.thesaigontimes.vn/Home/business/investment/19604/

Trompenaars, F. (2007). Managing change Across Corporate Cultures. England: Capstone Publishing Ltd.

Trompenaars, F., \& Turner, C. H. (2012). Riding the Waves of culture ( ${ }^{\text {rd }}$ ed.). U.S.A: Mc Graw Hill, p.204.

Varnholt H. (2015, September 28). Volkswagen's New CEO Says Car Maker Must Change Its Corporate Culture. The Wall Street Journal. Retrieved from http://www.wsj.com 